REVIEW

This paper is dedicated to the $70^{\text {th }}$ anniversary of the founding of Physiologia Bohemoslovaca (currently Physiological Research)

\title{
Pathophysiological Characteristics Linking Type 2 Diabetes Mellitus and Colorectal Neoplasia
}

\author{
Tomas GREGA ${ }^{\mathbf{1}}$, Gabriela VOJTECHOVA ${ }^{\mathbf{1}}$, Monika GREGOVA ${ }^{\mathbf{2}}$, Miroslav ZAVORAL ${ }^{\mathbf{1}}$, \\ Stepan SUCHANEK ${ }^{1}$
}

${ }^{1}$ Department of Internal Medicine, 1st Faculty of Medicine, Charles University, Military University Hospital in Prague, Czech Republic, ${ }^{2}$ Institute of Rheumatology and Department of Rheumatology, 1st Faculty of Medicine, Charles University, Prague, Czech Republic

Received December 14, 2020

Accepted March 18, 2021

Epub Ahead of Print June 2, 2021

\begin{abstract}
Summary
A substantial body of literature has provided evidence that type 2 diabetes mellitus (T2DM) and colorectal neoplasia share several common factors. Both diseases are among the leading causes of death worldwide and have an increasing incidence. In addition to usual risk factors such as sedentary lifestyle, obesity, and family history, common pathophysiological mechanisms involved in the development of these diseases have been identified. These include changes in glucose metabolism associated with adipose tissue dysfunction including insulin resistance resulting to hyperinsulinemia and chronic hyperglycemia. In addition to altered glucose metabolism, abdominal obesity has been associated with accented carcinogenesis with chronic subclinical inflammation. An increasing number of studies have recently described the role of the gut microbiota in metabolic diseases including T2DM and the development of colorectal cancer (CRC). Due to the interconnectedness of different pathophysiological processes, it is not entirely clear which factor is crucial in the development of carcinogenesis in patients with T2DM. The aim of this work is to review the current knowledge on the pathophysiological mechanisms of colorectal neoplasia development in individuals with T2DM. Here, we review the potential pathophysiological processes involved in the onset and progression of colorectal neoplasia in patients with T2DM. Uncovering common pathophysiological characteristics is essential for understanding the nature of these diseases and may lead to effective treatment and prevention.
\end{abstract}

\section{Key words}

Type 2 Diabetes Mellitus • Colorectal neoplasia • Cancer • Obesity - Microbiome

\section{Corresponding author}

Tomas Grega, Department of Internal Medicine, 1st Faculty of Medicine, Charles University, Military University Hospital in Prague, U Vojenske nemocnice 1200, 16902 Prague 6, Czech Republic. E-mail: tomas.grega@uvn.cz

\section{Introduction}

Colorectal cancer (CRC) is the third most common malignancy (1.8 million cases per year; $10.2 \%$ of the total cancer); it is the second most common cause of cancer-related deaths (Ferlay et al. 2019). The association between type 2 diabetes mellitus (T2DM) and $\mathrm{CRC}$ has been elucidated in numerous epidemiological studies and metanalyses (Zelenko et al. 2014; Suchanek et al. 2016). The risk of developing colorectal neoplasia is $20-50 \%$ higher in T2DM patients compared to the non-diabetic population (Buysschaert et al. 2013). A systemic analysis of eight selected studies showed a large correlation of T2DM with the 1.21-fold enhanced risk of colorectal neoplasia (Guraya et al. 2015).

Zhu et al. analyzed 36 cohort studies with 2,299,012 participants in 2017 to explore the relationship 
between T2DM and CRC. This meta-analysis revealed that the patients with T2DM will have a 5-year survival that is shorter than nondiabetic CRC patients. In addition, higher fasting blood glucose is associated with a higher cancer mortality. The correlation between elevated fasting glycemia and malignancy was described in 2011 by a working group in the United States (Seshasai et al. 2011). Fasting glucose levels greater than $5.6 \mathrm{mmol} / \mathrm{l}$ were associated with premature death in patients with malignancy. A significant linear relationship between fasting plasma glucose and the risk of CRC has been published in a systematic meta-analysis of 11 prospective studies (Shi et al. 2015). Each increase of plasma glucose by $20 \mathrm{mg} / \mathrm{dl}(1.1 \mathrm{mmol} / \mathrm{l})$ was associated with a $1.5 \%$ increase in incidence of CRC. Furthermore, a significant correlation between glycated hemoglobin (HbA1c) levels and CRC risk has also been demonstrated (Peila and Rohan 2020). Nevertheless, the biological mechanism linking diabetes and CRC is still unclear. Currently, it is hypothesized that hyperglycemia, insulin resistance with overexpression of insulin/insulin like growth factors (IGF), adipose tissue dysfunction, and gut microbiome may be key players in common pathogenesis of T2DM and CRC.

\section{Possible pathophysiological mechanisms}

Pathophysiological mechanisms linking T2DM and colorectal neoplasia potentially include hyperglycemia, chronic hyperinsulinemia, adipose tissue dysfunction, and changes in the microbiome (Table 1).

Table 1. Pathophysiological factors linking type 2 diabetes mellitus and colorectal cancer.

\section{Pathophysiological factors linking T2DM and CRC}

Hyperglycemia

Hyperinsulinemia and insulin resistance

Adipose tissue dysfunction

Microbiome

Because hyperglycemia and hyperinsulinemia are present in most diabetic patients, it is difficult to assess a specific role for carcinogenesis in each abnormality. The literature suggests that the role of hyperinsulinemia predominates in case of sufficient supply of nutrients. Animals with T2DM induced by pancreatic destruction (hyperglycemic and hypoinsulinemic animals) have smaller tumors than hyperglycemic and hyperinsulinemic animals (e.g., animals on insulin treatment). Chronic hyperinsulinemia has metabolic and mitogenic effects through the insulin receptors (Xu et al. 2016) and related insulin-like growth factor receptors (IGF-R). Animal models with precancerous colon adenomas have increased expression of insulin receptors, which supports the role of hyperinsulinemia in CRC development (Vella et al. 2018).

On the other hand, hyperglycemia and oxidative stress pathways can lead to cancer development through DNA damage and the accumulation of mutations (Ramteke et al. 2019). In animal study streptozotocininduced hyperglycemia increased liver metastasis of mouse colon cancer cells (González et al. 2017). This suggests that hyperglycemia per se may favor colorectal tumor growth and that hyperglycemia may be a significant stimulus for tumorigenesis in experimental animals. This assumption supports the finding that targeted treatment of hyperglycemia can lead not only to reducing of formation of $\mathrm{CRC}$, but also to improving of survival of CRC patients. In recent meta-analysis metformin reduces colorectal adenoma formation and colorectal cancer incidence ( $\mathrm{Ng}$ et al. 2020). Metformin use was also associated with better cancer survival.

Another common pathophysiological factor of T2DM and CRC is obesity, which is associated with adipose tissue dysfunction. It is characterized by chronic subclinical inflammation and insulin resistance (Stolarczyk et al. 2017). The link between chronic inflammation and carcinogenesis is due to oxidative stress and the production of cytokines and adipokines.

The gut microbiome and associated molecular mechanisms are also involved in the development of T2DM. Intestinal bacteria can also affect the process of oncogenesis, tumor progression, and response to treatment. Selective manipulation of the gut microbiome thus represents a potential tool to reduce the incidence of specific tumors in the general population and improve the effectiveness of cancer treatment. In addition, in patients with T2DM, selective intervention in the microbiome in combination with antidiabetic medication can lead to better therapeutic results. In this review article, we summarize recent findings regarding these pathophysiological processes in patients with T2DM and colorectal neoplasia.

\section{Hyperglycemia}

Chronic hyperglycemia is associated with a higher incidence of carcinogenesis by oncogene activation and inactivation of tumor suppressor genes. 


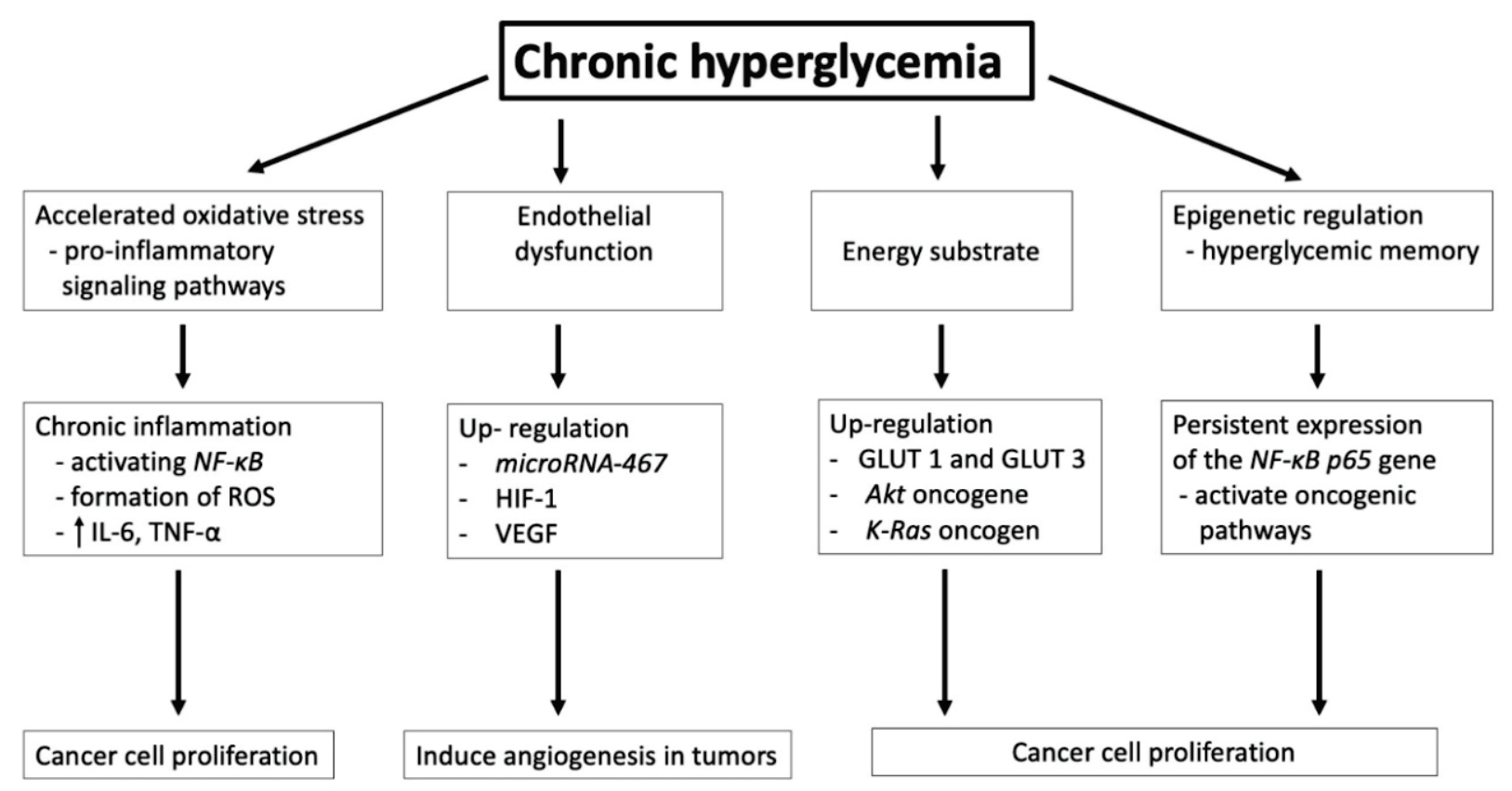

Fig. 1. Effect of chronic hyperglycemia in carcinogenesis. NF-KB: transcription nuclear factor $\kappa B$; ROS: reactive oxygen species; IL-6: Interleukin-6; TNF-a: tumor necrosis factor-alfa; HIF-1: hypoxia inducible factor 1; VEGF: vascular endothelial growth factor; GLUT 1, GLUT 3: glucose transporters 1 and 3.

There are several pathophysiological mechanisms involved in these processes (Fig. 1).

\section{Stimulation of chronic inflammation}

Hyperglycemia can stimulate chronic inflammation and tissue damage by chronic accumulation of glycated biomolecules and advanced glycation end products (AGEs) (Schröter and Höhn 2018). The formation of AGEs is a complex cascade of glycation reactions of different kinds of biomolecules including proteins, lipids and nucleic acids. AGEs may covalently crosslink and biochemically modify structure and functions of many proteins, including the interstitial connective tissue matrix and the basement membrane (Rojas et al. 2018). Additionally, higher concentration of different AGEs leads to increased AGEs receptor (RAGE) binding with subsequent acceleration of chronic inflammation performed by enhanced gene growth factors or cytokines expression (Škrha Jr et al. 2014). Activation of RAGE increases the secretion of stromal cells cytokines/chemokines secretion and thus leading to the recruitment and activation of inflammatory cells into the tumor microenvironment. Inflammatory cytokines (such as interleukin 6 and tumor necrosis factor- $\alpha$ ) are released to chemotactically attract macrophages and regulatory $\mathrm{T}$ cells involved in chronic inflammation stimulation and angiogenesis. Inflammatory cytokines can stimulate the process of carcinogenesis through autocrine and paracrine activation of oncogenic signaling pathways in macrophages and enteroendocrine cell lines (Cosin-Roger et al. 2019).

Besides AGEs, RAGE also binds to other structurally unrelated ligands, such as amyloid-forming peptides and proteins, the high mobility group box 1 protein (HMGB1), the complement receptor macrophage1 antigen (Mac-1) and S100 proteins, which are involved in the development and progression of CRC (Donato et al. 2013). The RAGE activation leads to formation of numerous intracellular signaling mechanisms, resulting in the progression and prolongation of oxidative stress, inflammation, and tumorigenesis. Moreover, RAGE expression correlates well with the survival of colon cancer cells (Aizian-Farsani et al. 2020).

Ligand-mediated activation of RAGE triggers increased activation of pro-inflammatory transcriptional

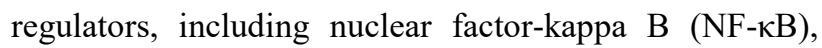
signal transducer activator of transcription 3 (STAT3), hypoxia inducible factor 1 (HIF-1) and even microRNAs. MicroRNAs (miRNAs) are small non-coding single stranded RNAs, which control the gene expression by degrading the corresponding mRNA, destabilizing and/or inhibiting their translation (Frixa et al. 2015). MicroRNAs can act as onco-miRNAs or anti-oncomiRNAs depending on their potential target genes. After RAGE activation, transcription factors migrate into the nucleus, interact with the DNA and lead to increased 
expression of pro-inflammatory cytokines, enzymes, as well as oncogenes with associated downregulation of tumor suppressor genes (Bongarzone et al. 2017). This cascade generates overexpression of RAGE and its ligands, such as AGEs, S100 proteins and HMGB1 which leads to a positive feedback loop and further RAGE upregulation. The stimulation of RAGE in colorectal cancer cells by $\mathrm{S} 100 \mathrm{P}$ proteins contributes to activation of transcription factors (activator protein 1 (AP-1) and $\mathrm{NF}-\mathrm{KB}$ ) through mitogen-activated protein kinase (MEK), extracellular signal-regulated kinases (ERK) phosphorylation, and increased expression of oncogenes such as miRNA-155 and miRNA-21, that are up-regulated in human colon cancer cells (MercadoPimentel et al. 2015). Antagonism of RAGE activity with the anti-RAGE antibodies results to reduction in cell growth, migration, and invasiveness.

Production of reactive oxygen species (ROS) by activation of RAGE can damage the cellular components (DNA, proteins, and cell membrane lipids) that contribute to the transformation of malignant cells. In addition, oxidative stress is directly connected with overproduction of superoxide in mitochondria, which leads to mitochondrial dysfunction with impaired insulin secretion by pancreatic $\beta$-cells (Zińczuk et al. 2019, Urbanova et al. 2017). This theory of chronic inflammation is supported by the observation that nonsteroidal anti-inflammatory drugs reduce the risk of $\mathrm{CRC}$ in predisposed individuals.

\section{Endothelial dysfunction}

High serum glucose levels lead to DNA damage in human endothelial cells including the development of endothelial dysfunction and pathological angiogenesis (Shi et al. 2015). Hyperglycemia has recently been shown to induce angiogenesis in tumors by upregulating microRNA-467 - a suppressor of the antiangiogenic protein thrombospondin-1 resulting in tumor neoangiogenesis and malignant growth (Chang and Yang 2016, Bhattacharyya et al. 2012).

The tumor microenvironment is characterized by hypoxia with insufficient coverage of its energy requirements, and thus critical cellular adaptations and changes are initiated in the hypoxemic environment. The survival of cells exposed to hypoxic stress depends on the increased expression of genes supporting anaerobic metabolism and the emergence of new metabolites in the bloodstream. Activation of these hypoxic genes is controlled by the hypoxia inducible factor 1 (HIF-1).
High expression of this factor correlates with higher tumor aggressiveness, faster proliferation, and greater expression of the important activator of angiogenesis endothelial vascular growth factor (VEGF) (Qi et al. 2020).

\section{Energy substrate}

Chronic hyperglycemia acts as an energy substrate in the process of carcinogenesis. Glucose is an essential source of energy for the metabolism of tumor cells while chronic hyperglycemia provides ideal conditions for stimulating their proliferation. In the hypoxic microenvironment of the tumor, glucose transporters (especially GLUT 1 and GLUT 3) are upregulated, and the tumor cell transitions to a glycolytic phenotype of glucose metabolism. In addition to hypoxia, mutations in certain oncogenes can also induce overexpression and activity of glycolytic enzymes and GLUT. These include the Akt oncogene encoding a serine/threonine kinase that promotes aerobic glycolysis of a tumor cell (Hoxhaj and Manning 2020). Another oncogene, $K$-Ras can alter glucose metabolism by giving tumor cells a selective advantage. Cells with mutated $K$-Ras have increased expression of the glucose transporter GLUT1 (Ancey et al. 2018).

Anaerobic glycolysis is typical for tumor cells and arises as a metabolic adaptation to rapid tumor growth in hypoxic conditions at the expense of mitochondrial oxidative phosphorylation. Transformed cells remain in a glycolytic mechanism even in the presence of oxygen (so-called aerobic glycolysis, Warburg effect). Here, a large amount of lactate is produced from pyruvate, and the $\mathrm{pH}$ of the extracellular environment decreases (Jiang 2017). This aerobic glycolysis is often considered to be the seventh sign of cancer along with selective growth and proliferative advantage, altered stress response favoring overall survival, vascularization, invasion and metastasis, an abetting microenvironment and immune modulation (Fouad and Aanei 2017). Glycolysis is much faster than oxidative phosphorylation, and it can produce more ATP (adenosine triphosphate) by glycolysis over time than when oxidative phosphorylation is involved (if high glucose intake is ensured). Tumor cells preferentially utilize glycolysis only under conditions of sufficient glucose concentration. When extracellular glucose levels are reduced, tumor cells start to use slower mitochondrial respiration (Potter et al. 2016). 


\section{Epigenetic regulation}

Elevated glucose levels disrupt epigenetic regulation leading to "hyperglycemic memory" a condition that allows tumor cells exposed to hyperglycemia to permanently activate oncogenic pathways even after normalization of fasting glucose levels. The activation of hyperglycemic memory has been linked to generation of oxidative stress and AGEs, and activation of the mitogen activated protein kinase pathway. Recent studies have also implicated epigenetic mechanisms in the development of hyperglycemic memory. One example of hyperglycemic memory includes the upregulation of $N F \kappa B-p 65$ gene expression as a result of prior hyperglycemia (Al-Haddad et al. 2016).

\section{Chronic hyperinsulinemia}

Hyperinsulinemia plays a significant role in carcinogenesis through its proliferative action via insulin receptors (IR), stimulation of insulin-like growth factor (IGF), and its receptor (IGF-R) (Hua et al. 2020). While IR activation leads mainly to metabolic effects, binding to IGF-R leads to cell proliferation, angiogenesis, and subsequent metastasis (Fig. 2).

There are two main isoforms of IR: IR-A and IR-B (Vella et al. 2018). IR-A is expressed at high levels in fetal and neoplastic tissues, binds insulin and IGF, and mediates mainly antiapoptotic and mitogenic effects. IRB predominantly binds insulin and has metabolic effects. IR-B is expressed in tissues such as liver, muscle, adipocytes, and kidney. IGF-R can be stimulated by both IGF and insulin, and their activation has greater mitogenic and transformational potential. Due to the high degree of homology between IR and IGF-R, there are also hybrid receptors for insulin and IGF (IGF-IR) that are overexpressed in tumor cells (Simpson et al. 2017). Hybrid receptors behave more like IGF-R because they have a higher affinity for IGF. Thus, they provide additional binding sites for IGF and have mitogenic and antiapoptotic effects. In addition, insulin increases the amount of bioavailable IGF because it inhibits the production of two IGF-binding proteins (IGFBP-1 and IGFBP-2), which are necessary to transport IGF to peripheral tissues.

In the case of insulin resistance and subsequent hyperinsulinemia, the mitogenic pathway of insulin is enhanced along with collateral binding of insulin and IGF to the IGF-R. IR (especially the fetal isoform IR-A) and IGF-R are overexpressed in tumor cells resulting in overexpression of hybrid IGF-IR. (Scalia et al. 2020). As mentioned above, hyperinsulinemia is associated with a decrease in circulating IGF-binding proteins resulting in an increase of free IGF and overstimulation of IGF-R and hybrid receptors. These abnormalities all lead to overgrowth of tumor cells and progressive development of precancerous lesions. Insulin-induced oncogenic signaling pathways involve the activation of multiple neoplastic protein kinases - especially mitogen-activated protein kinases (MAPK) and the extracellular signalregulated kinase (ERK).

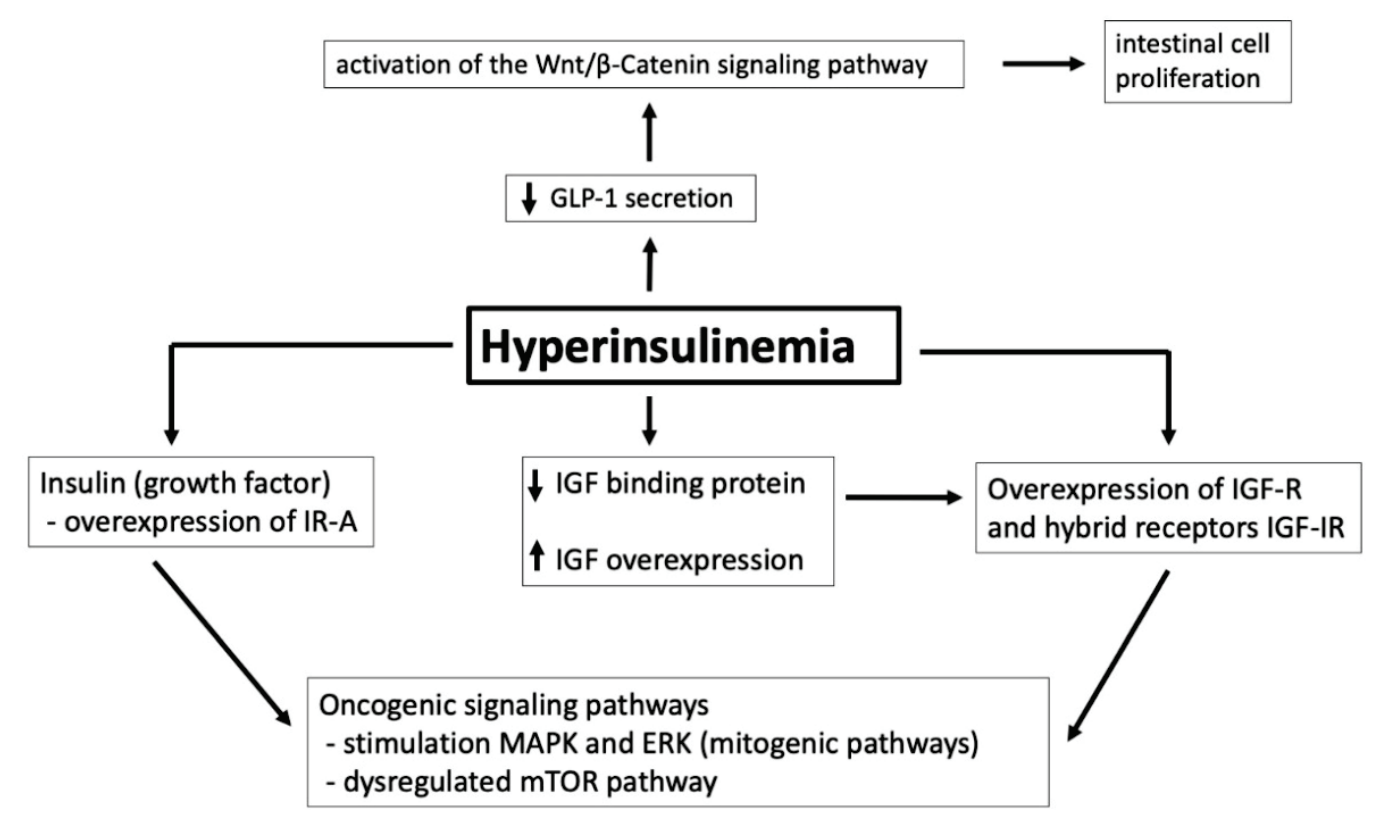

Fig. 2. The role of hyperinsulinemia in carcinogenesis. IR-A: insulin receptor - isoform A; IGF: insulin-like growth factor; IGF-R: receptor for insulin-like growth factor; IGF-IR: hybrid receptor for insulin and insulin-like growth factor; MAPK: mitogen-activated protein kinases; ERK: extracellular signal-regulated kinase; mTOR: mammalian target of rapamycin; GLP-1: glucagon-like peptide-1. 
Potentiation of growth factors with proliferative activity affects cellular metabolism and the mammalian target of rapamycin (mTOR) pathway. Such activation in turn leads to increased sensitivity of colon cells to growth factors and accelerated progression from adenoma to carcinoma (Conciatori et al. 2018). Increased insulin level and free IGF stimulate cell growth and proliferation, reduce apoptosis, and increase vascular endothelial growth factor levels, which promote colorectal carcinogenesis (Kasprzak and Adamek 2019).

Another possible molecular mechanism for the link between high insulin levels and CRC risk involves the hormone glucagon-like peptide-1 (GLP-1), which is secreted by intestinal endocrine L cells. Due to insulin resistance, decreased GLP-1 secretion leads to a compensatory activation of the $\mathrm{Wnt} / \beta$-Catenin signaling pathway in combination with increased expression of oncogenes such as $c-M y c$ and cyclin D1. This in turn leads to intestinal cell proliferation and the development of CRC (Giouleme et al. 2011).

\section{Adipose tissue dysfunction}

Most patients (80-90\%) with T2DM are overweight or obese (Flegal et al. 2012). Obesity is associated with a higher tumor incidence and mortality. Several systematic reviews and meta-analyzes have shown that the relative risk of CRC associated with obesity (as defined by a body mass index $(\mathrm{BMI}) \geq 30 \mathrm{~kg} / \mathrm{m}^{2}$ ) was higher in men. Abdominal obesity characterized by waist circumference or waist to hip ratio (WHR) has shown a higher relative risk of colon cancer in both sexes (Wang et al. 2017). This evidence suggests that visceral adipose tissue (VAT) is more associated with the development and progression of colorectal neoplasia, and WHR measurements are more appropriate for CRC risk assessment. Compared to subcutaneous adipose tissue (SCAT), overall VAT is considered to be more metabolically and endocrine-active overall. The VAT produces higher levels of proinflammatory cytokines, adipokines, and free fatty acids (Burhans et al. 2018).

Obesity is associated with adipose tissue dysfunction (Fig. 3) whose hallmarks are chronic subclinical inflammation and insulin resistance (Stolarczyk et al. 2017). The association between chronic inflammation and carcinogenesis is characterized by oxidative stress and the production of cytokines and adipokines. Adipose tissue acts as an endocrine organ producing many biologically active substances involved in the regulation of metabolism (Booth et al. 2016). Excessive accumulation of fat stores leading to obesity is the basis for altered endocrine production of adipokines and cytokines in adipose tissue such as leptin, adiponectin, interleukin 6 (IL-6), and tumor necrosis factor alpha (TNF- $\alpha$ ) (Divella et al. 2016). The chronic inflammatory condition associated with high levels of cytokines creates a carcinogenic environment that promotes angiogenesis (Aguilar-Cazares et al. 2019). Furthermore, high cytokine production leads to insulin resistance (Shi et al. 2019). Metabolic and mitogenic changes induced by excessive fat depots increase the carcinogenic effect of hyperglycemia and hyperinsulinemia observed in T2DM.

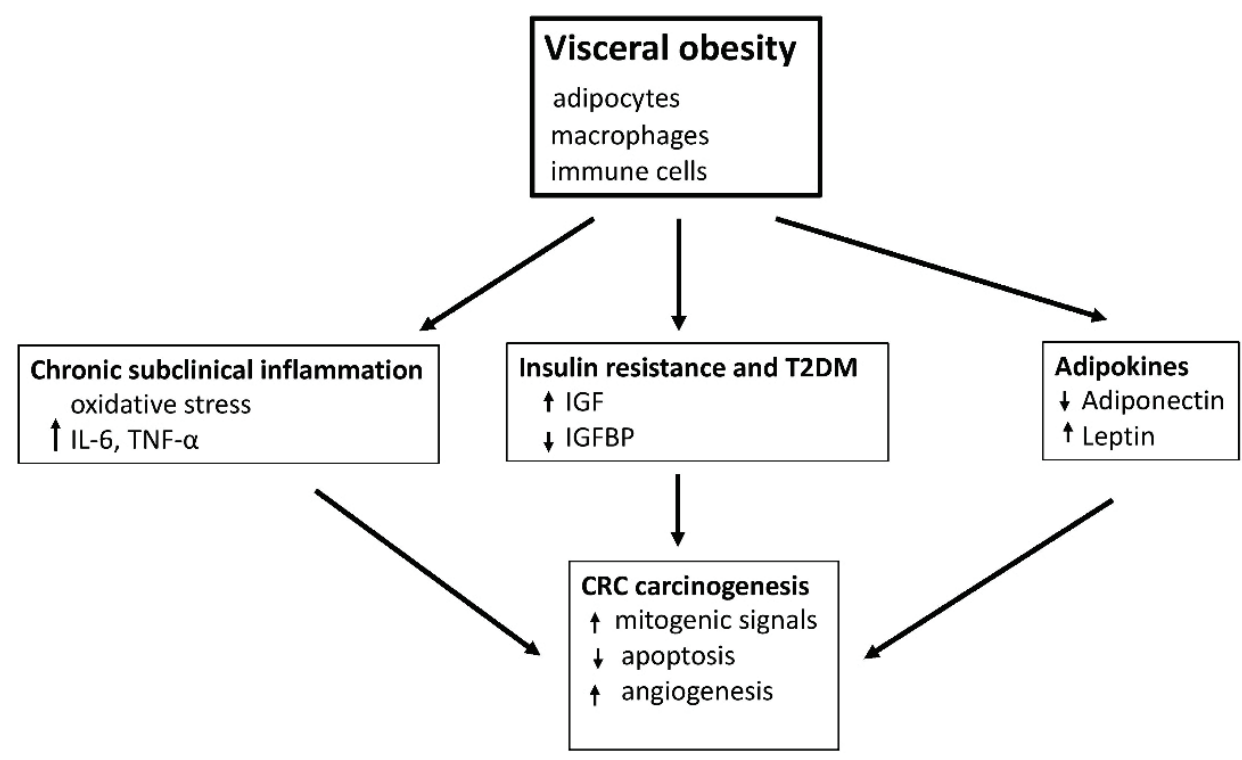

Fig. 3. Mechanisms linking visceral obesity to colorectal cancer. IL-6: Interleukin-6; TNF-a: tumor necrosis factor-alfa; IGF: insulin-like growth factor; IGFBP: insulin-like growth factor binding protein; T2DM: type 2 diabetes mellitus. 


\section{Hormonal production of adipose tissue}

Adipose tissue is a source of polypeptide hormones, i.e., adipokines. These adipokines act as paracrine and endocrine signaling molecules. Excessive amounts of VAT can be associated with dysregulation of adipokine expression, which is a mechanism in CRC. Major adipokines directly related to colorectal carcinogenesis include leptin and adiponectin. These adipokines show the opposite activity when excessive adipose tissue accumulates: concentration of leptin increases, and the concentration of adiponectin decreases.

Leptin is involved in the control of food intake and energy expenditure (Pandit et al. 2017). Leptin overexpression has mitogenic (Al-Shibli et al. 2019) and antiapoptotic effects (Samad and Rao 2019). It promotes the invasiveness of colon adenomatous cells (Yoon et al. 2014) and its increased expression correlates with the progression of colorectal carcinogenesis (Modzelewska et al. 2019). Leptin induces its effects through its receptor. As a result, the phosphatidylinositol 3-kinase (PI3K), MAPK, and signal transducer and activator of the transcriptional (STAT) signaling pathway are activated. The possible effects of leptin on tumor angiogenesis have not yet been fully elucidated. One of the most debated hypotheses is the paracrine stimulation of new blood vessel formation by endothelial cells expressing the leptin receptor (Philippa et al. 2018) and the effects of leptin similar to IGF-1 (Ashktorab et al. 2011). A clinical study conducted in a cohort of patients with colorectal carcinoma has found that almost $80 \%$ of cases are characterized by the presence of leptin receptors in the lesion. This correlates positively with cancer-related angiogenesis and cellular proliferation (Milosevic et al. 2015). The authors suggest that leptin profile could be used as a biomarker to select those patients who are at high risk of developing an aggressive form of colorectal cancer.

Adiponectin has protective effects in the process of carcinogenesis. Its increased concentration is inversely associated with insulin levels and amount of VAT. Serum adiponectin levels are indirectly associated with colorectal cancer (Katira and Tan 2016). Adiponectin acts through its receptors (ADIPOR1 and ADIPOR2) in target tissues. Activation of these receptors suppresses inflammation, increases cell sensitivity to insulin, induces apoptosis, and inhibits cell proliferation (Renehan et al. 2015). Adiponectin activates AMP-activated protein kinase (adenosine monophosphate-activated protein kinase or AMPK) signaling pathways, which activate tumor suppressor genes $p 53$ and $p 21$ and subsequently cell apoptosis (Moon et al. 2013). The AMPK activated pathway also inhibits $\mathrm{PI} 3 \mathrm{~K} / \mathrm{AKT} / \mathrm{mTOR}$ signaling pathways, which are essential for carcinogenesis (Renehan et al. 2015).

\section{Macrophage infiltration and activity in adipose tissue}

The association of VAT with the induction of subclinical inflammation is closely related to macrophage activity. First, preadipocytes (stem mesenchymal cells) can show strong phagocytic activity in the condition of obesity and thus serve as macrophages (Riondino et al. 2014). The plasticity of mesenchymal cells is much greater than previously considered (Shin et al. 2020). Second, in the case of obesity, VAT is infiltrated by macrophages, which enter adipose tissue from the systemic circulation. These are probably recruited by several mechanisms that are not entirely clear (Bai and Sun 2016, Castoldi et al. 2016). An increase in macrophage numbers correlates with an increase in BMI and adipocyte hypertrophy. Third, adipocytes interact with macrophages and synergistically stimulate the inflammatory response (Thomas and Apovian 2011). Macrophages infiltrating the VAT show a transition from anti-inflammatory and adipostatic phenotype (M2 macrophages) to pro-inflammatory and proadipogenic phenotype (M1 macrophages). M1 macrophages are source of proinflammatory cytokines such as TNF- $\alpha$ and IL-6. In addition, they produce free ROS and inducible NO synthase (iNOS), which are associated with the development of insulin resistance (Castaneda et al. 2017). Obesity leads to a shift in the proportion of the M1 macrophage subpopulation with increased production of proinflammatory cytokines and ROS that contributes to chronic subclinical inflammation, insulin resistance, and T2DM. Dysregulated M1/M2 macrophage balance also explains carcinogenesis in obese patients with T2DM (Hao et al. 2012).

\section{Microbiome}

Microbiome changes are associated with the pathophysiology of most chronic diseases. Dysbiosis and associated chronic subclinical inflammation of the intestinal wall contribute to the development of chronic gastrointestinal diseases such as inflammatory bowel disease, irritable bowel syndrome, or colorectal neoplasia (Dabke et al. 2019). In addition to intestinal effects, dysbiosis is associated with the development of 
extraintestinal chronic diseases - most commonly obesity and T2DM. There is evidence that changes in the microbiome can impact glucose metabolism in animal models (Gurung et al. 2020). In addition, preclinical and clinical studies suggest that the microbiome is also strongly associated with oncogenesis including CRC.

\section{The composition of the gut microbiome}

A typical human gut microbiome contains $10^{10}$ microorganisms, which is similar to the total number of human cells (Pabst et al. 2017). Metagenomic studies have identified a huge and diverse group of microbial genes. It is estimated that they encode a 100 -fold more unique genes than our own genome (Qin et al. 2010). The 16S rRNA sequencing (ribosomal RNA gene) and mass spectrometry with fly-through analyzer and matrix laser desorption ionization significantly improved the identification of bacterial species and pathogenic microorganisms in clinical microbiology laboratories (Fournier et al. 2013, Lagier et al. 2015). It is currently estimated that a fragile community of commensal organisms produces 500-1000 different bacterial species and more than 7,000 individual bacterial strains.

Depending on the site of location, the composition of the microbiome varies significantly (The Human Microbiome Project Consortium, 2012). The vast majority of commensal microorganisms are found in the large intestine with an estimated up to $10^{13}$ bacteria. Most species isolated from humans $(93.5 \%)$ belong to four bacterial strains: Firmicutes, Proteobacteria, Actinobacteria and Bacteroidetes (Hugon et al. 2015). The presence of Proteobacteria is quite low, and its absence suggests a healthy intestinal microbiome (Hollister et al. 2014). Proteobacteria form a diverse group of gram-negative microorganisms and include the species Klebsiella (a significant nosocomial pathogen) and the Escherichia coli (involved in the development of CRC).

The presence and dominance of individual species is highly dynamic and is constantly influenced by the external environment, genetics, host immune system, infection, and treatment with antibiotics or other drugs (Belizário and Napolitano 2015). Microbiotic composition and function also vary according to different geography, age, sex, race, and diet (Hollister et al. 2014).

Colorectal tumors in humans show significantly higher amounts of Proteobacteria and lower numbers of Bacteroidetes (Shen et al. 2010). Bacterial strains positively associated with the occurrence of T2DM were Ruminococcus, Fusobacterium, and Blautia (Sedighi et al. 2017) (Table 2). Castellarin et al. (2012) showed that the DNA of Fusobacterium nucleatum is increased in CRC tumor tissue and correlates with lymph node metastases. Kostic et al. (2012) found that the presence of Fusobacterium spp. was generally higher in fecal samples of CRC patients compared to healthy controls. F. nucleatum also contributes to colorectal cancer resistance to chemotherapy through a complex network of mechanisms including toll-like receptor signaling, microRNAs, and induction of autophagy (Ramos et al. 2017).

\section{Pathophysiological effects of microbiome}

The complex interactions of the gut microbiome with the intestinal mucosa plays a key role in the pathogenesis of T2DM similar to other diseases such as obesity, inflammatory bowel disease, and CRC. The microbiome influences the development of chronic subclinical inflammation, intestinal wall permeability and translocation of bacterial agents, glucose homeostasis (including insulin resistance), and fatty acid synthesis. Dysbiosis can also lead to genetic and epigenetic changes leading to the development of dysplasia, clonal expansion, and malignant transformation of colon cells. Initiation and progression of colorectal carcinogenesis may be the result of direct microbiome action through bacterial metabolites or stimulation of chronic subclinical inflammation.

In addition, microbiota have a great influence on the expression of a wide range of human genes. For example, specific strains of Bifidobacteria, Lactobacilli, and Escherichia coli affect the gene expression of caspase and toll-like receptors (TLR) on macrophages and dendritic cells, which modulate immunological activity and apoptosis (Plaza-Diaz et al. 2014). The interaction between the microbiome and immune cells creates a delicate balance between pro-inflammatory genes and proto-oncogenes with anti-inflammatory genes and tumor suppressor genes.

Table 2. Common bacterial strains associated with type 2 diabetes mellitus and colorectal cancer.

\section{Composition of gut microbiome (bacterial strains)}

$\begin{array}{lc}\begin{array}{l}\text { Type } 2 \text { diabetes } \\ \text { mellitus }\end{array} & \begin{array}{c}\text { Ruminococcus } \\ \text { Fusobacterium } \\ \text { Blautia }\end{array} \\ \text { Colorectal cancer } & \text { Fusobacterium } \\ & \text { Proteobacteria }\end{array}$




\section{Future perspectives}

There is considerable interest in the potential use of the microbiome in clinical practice especially in the treatment of chronic metabolic diseases and oncological diseases. Although the composition of the microbiome is stable for each individual over a long time, there are many factors (aging, obesity, Western diet, lack of exercise, disease, and antibiotics) that lead to a change in the microbiome towards less diversity and proinflammatory profiles including higher rates of certain pro-tumorigenic bacteria (fusobacteria and proteobacteria) associated with CRC.

Hypothetically, selective modulation of the gut microbiome can be used in anticancer therapy and T2DM therapy. Four different methods can be used to affect the microbiome: (1) antibiotics-drugs with preferential cytotoxicity for one or more bacterial species; (2) probiotics - live bacteria or other micro-organisms that provide health benefits (when administered in sufficient quantities); (3) prebiotics - indigestible compounds that stimulate the growth and/or function of specific components of the gut microbiome; (4) so-called postbiotics - non-viable products of the gut microbiome that stimulate biological activities in the host (Zitvogel et al. 2015).

Specific changes in the gut microbiome can serve as a tool to increase the efficacy of antidiabetics in T2DM or chemotherapeutics in CRC. At the same time, these changes can reduce the side effects of cancer treatment. In the context of antibiotics, the main obstacles may be the limited selectivity of most conventional antibiotics and the increased interindividual heterogeneity of the gut microbiome. Highly specific antimicrobial agents and the development of new technologies enabling rapid and detailed characterization of the gut microbiome on a personnel basis can at least partially circumvent these problems.

An example of selective modulation of microbiome for therapeutic purposes may be the administration of Lactobacillus rhamnosus, which reduces the expression of $\beta$-catenin and inflammatory proteins NFкB-p65 while inducing the expression of proapoptotic proteins $\mathrm{p} 53$ and Bax (Gamallat et al. 2016). In 27 studies involving 206 patients receiving radiotherapy, L. rhamnosus reduced radiation-related gastrointestinal toxicity (Urbancsek et al. 2001).
Lactobacillus acidophilus 606 also exhibits antitumor activity against human colon cancer cells (Kim et al. 2010). A study investigating the effects of the probiotic Bifidobacterium animalis ssp. Lactis 420, a prebiotic of polydextrose in combination with sitagliptin in diabetic mice (Stenman et al. 2015), was more effective in reducing several T2DM parameters. A similar study in diabetic rodent models found that the combination of a prebiotic polysaccharide with the antidiabetic drugs metformin and sitagliptin reduced hyperglycemia and adiposity compared to the antidiabetic drugs alone (Reimer et al. 2014). In another study, streptozotocininduced diabetic mice treated with combination of a prebiotic and metformin showed improvements in fasting glucose, glucose tolerance, and insulin resistance compared to metformin alone (Zheng et al. 2018).

\section{Conclusion}

Pathophysiological processes involved in the onset and progression of colorectal neoplasia in patients with T2DM are complex and include the effects of chronic hyperglycemia, hyperinsulinemia, adipose tissue dysfunction, and gut microbiome changes. The gradual discovery of complex mutual connections allows us to better perceive these diseases. Despite the significant advances in understanding the pathogenesis of T2DM and oncogenesis of CRC itself, there are still many unknowns in the area linking these pathological conditions. Further research is needed to reveal the common characteristics and pathophysiological processes of carcinogenesis in T2DM. A clear identification of these processes will then contribute to a better understanding of the nature of these diseases and their interconnection, which is the basis of effective prevention and therapy.

\section{Conflict of Interest}

There is no conflict of interest.

\section{Acknowledgements}

Supported by MO 1012, Progres Q28/LF1 and by the Czech Health Research Council of the Czech Ministry of Health research grants AZV 16-29614A, AZV 17-31909A and NV18-08-00246. 


\section{References}

AGUILAR-CAZARES D, CHAVEZ-DOMINGUEZ R, CARLOS-REYES A, LOPEZ-CAMARILLO C, HERNADEZ DE LA CRUZ ON, LOPEZ-GONZALEZ JS: Contribution of angiogenesis to inflammation and cancer. Front Oncol 9: 1399, 2019. https://doi.org/10.3389/fonc.2019.01399

AL-HADDAD R, KARNIB N, ASSAAD RA, BILEN Y, EMMANUEL N, GHANEM A, YOUNES J, ZIBARA V, STEPHAN JS, SLEIMAN SF: Epigenetic changes in diabetes. Neurosci Lett 625: 64-69, 2016. https://doi.org/10.1016/j.neulet.2016.04.046

AL-SHIBLI SM, HARUN N, ASHOUR AE, MOHD KASMURI MHB, MIZAN S: Expression of leptin and leptin receptors in colorectal cancer-an immunohistochemical study. PeerJ 7: e7624, 2019. https://doi.org/10.7717/peerj.7624

ANCEY PB, CONTAT C, MEYLAN E: Glucose transporters in cancer - from tumor cells to the tumor microenvironment. FEBS J 285: 2926-2943, 2018. https://doi.org/10.1111/febs.14577

ASHKTORAB H, SOLEIMANI A, NICHOLS A, SODHI K, LAIYEMO AO, NUNLEE-BLAND G, NOURAIE SM, BRIM H: Adiponectin, leptin, IGF-1, and tumor necrosis factor alpha as potential serum biomarkers for noninvasive diagnosis of colorectal adenoma in african americans. Front Endocrinol (Lausanne) 9: 77, 2018. https://doi.org/10.3389/fendo.2018.00077

AZIZIAN-FARSANI F, ABEDPOOR N, HASAN SHEIKHHA M, GURE AO, NASR-ESFAHANI MH, GHAEDI K: Receptor for advanced glycation end products acts as a fuel to colorectal cancer development. Front Oncol 10: 552283, 2020. https://doi.org/10.3389/fonc.2020.552283

BAI Y, SUN Q: Macrophage recruitment in obese adipose tissue. Obes Rev 16: 127-136, 2015. https://doi.org/10.1111/obr.12242

BELIZÁRIO JE, NAPOLITANO M: Human microbiomes and their roles in dysbiosis, common diseases, and novel therapeutic approaches. Front Microbiol 6: 1050, 2015. https://doi.org/10.3389/fmicb.2015.01050

BHATTACHARYYA M, DAS M, BANDYOPADHYAY S: miRT: a database of validated transcription start sites of human microRNAs. Genomics Proteomics Bioinformatics 10: 310-316, 2012. https://doi.org/10.1016/j.gpb.2012.08.005

BONGARZONE S, SAVICKAS V, LUZI F, GEE AD: Targeting the Receptor for Advanced Glycation Endproducts (RAGE): A medicinal chemistry perspective. J Med Chem 60: 7213-7232, 2017. https://doi.org/10.1021/acs.jmedchem.7b00058

BOOTH A, MAGNUSON A, FOUTS J, FOSTER MT: Adipose tissue: an endocrine organ playing a role in metabolic regulation. Horm Mol Biol Clin Investig 26: 25-42, 2016. https://doi.org/10.1515/hmbci-2015-0073

BURHANS MS, HAGMAN DK, KUZMA JN, SCHMIDT KA, KRATZ M: Contribution of adipose tissue inflammation to the development of type 2 Diabetes Mellitus. Compr Physiol 9: 1-58, 2018. https://doi.org/10.1002/cphy.c170040

BUYSSCHAERT M, SADIKOT S: Diabetes and cancer: a 2013 synopsis. Diabetes Metab Syndr 7: 247-250, 2013. https://doi.org/10.1016/j.dsx.2013.08.001

CASTANEDA OA, LEE SC, HO CT, HUANG TC: Macrophages in oxidative stress and models to evaluate the antioxidant function of dietary natural compounds. J Food Drug Anal 25: 111-118, 2017. https://doi.org/10.1016/j.jfda.2016.11.006

CASTELLARIN M, WARREN RL, FREEMAN JD, DREOLINI L, KRZYWINSKI M, STRAUSS J, BARNES R, WATSON P, ALLEN-VERCOE E, MOORE RA, HOLT RA: Fusobacterium nucleatum infection is prevalent in human colorectal carcinoma. Genome Res 22: 299-306, 2012. https://doi.org/10.1101/gr.126516.111

CASTOLDI A, NAFFAH DE SOUZA C, CÂMARA NO, MORAES-VIEIRA PM: The Macrophage Switch in Obesity Development. Front Immunol 6: 637, 2016. https://doi.org/10.3389/fimmu.2015.00637

CHANG SC, YANG WV: Hyperglycemia, tumorigenesis, and chronic inflammation. Crit Rev Oncol Hematol 108: 146-153, 2016. https://doi.org/10.1016/j.critrevonc.2016.11.003

CONCIATORI F, BAZZICHETTO C, FALCONE I, PILOTTO S, BRIA E, COGNETTI F, MILELLA M, CIUFFREDA L: Role of mTOR signaling in tumor microenvironment: an overview. Int J Mol Sci 19: 2453, 2018. https://doi.org/10.3390/ijms19082453 
COSIN-ROGER J, ORTIZ-MASIÀ MD, BARRACHINA MD: Macrophages as an emerging source of Wnt ligands: relevance in mucosal integrity. Front Immunol 10: 2297, 2019. https://doi.org/10.3389/fimmu.2019.02297

DABKE K, HENDRICK G, DEVKOTA S: The gut microbiome and metabolic syndrome. J Clin Invest 129: 4050-4057, 2019. https://doi.org/10.1172/JCI129194

DIVELLA R, DE LUCA R, ABBATE I, NAGLIERI E, DANIELE A: Obesity and cancer: the role of adipose tissue and adipo-cytokines-induced chronic inflammation. J Cancer 7: 2346-2359, 2016. https://doi.org/10.7150/jca.16884

DONATO R, CANNON BR, SORCI G, RIUZZI F, HSU K, WEBER DJ, GECZY CL: Functions of S100 proteins. Curr Mol Med 13: 24-57, 2013. https://doi.org/10.2174/156652413804486214

FERLAY J, COLOMBET M, SOERJOMATARAM I, MATHERS C, PARKIN DM, PIÑEROS M, ZNAOR A, BRAY F: Estimating the global cancer incidence and mortality in 2018: GLOBOCAN sources and methods. Int $\mathrm{J}$ Cancer 144: 1941-1953, 2019. https://doi.org/10.1002/ijc.31937

FERNÁNDEZ-REAL JM, BROCH M, VENDRELL J, RICART W: Insulin resistance, inflammation, and serum fatty acid composition. Diabetes Care 26: 1362-1368, 2003. https://doi.org/10.2337/diacare.26.5.1362

FLEGAL KM, CARROLL MD, KIT BK, OGDEN CL: Prevalence of obesity and trends in the distribution of body mass index among US adults, 1999-2010. JAMA 307: 491-497, 2012. https://doi.org/10.1001/jama.2012.39

FOUAD YA, AANEI C: Revisiting the hallmarks of cancer. Am J Cancer Res 7: 1016-1036, 2017.

FOURNIER PE, DRANCOURT M, COLSON P, ROLAIN JM, LA SCOLA B, RAOULT D: Modern clinical microbiology: new challenges and solutions. Nat Rev Microbiol 11: 574-585, 2013. https://doi.org/10.1038/nrmicro3068

FRIXA T, DONZELLI S, BLANDINO G: Oncogenic microRNAs: key players in malignant transformation. Cancers (Basel) 7: 2466-2485, 2015. https://doi.org/10.3390/cancers7040904

GAMALLAT Y, MEYIAH A, KUUGBEE ED, HAGO AM, CHIWALA G, AWADASSEID A, BAMBA D, ZHANG X, SHANG X, LUO F, XIN Y: Lactobacillus rhamnosus induced epithelial cell apoptosis, ameliorates inflammation and prevents colon cancer development in an animal model. Biomed Pharmacother 83: 536-541, 2016. https://doi.org/10.1016/j.biopha.2016.07.001

GIOULEME O, DIAMANTIDIS MD, KATSAROS MG: Is diabetes a causal agent for colorectal cancer? Pathophysiological and molecular mechanisms. World J Gastroenterol 17: 444-448, 2011. https://doi.org/10.3748/wjg.v17.i4.444

GONZÁLEZ N, PRIETO I, DEL PUERTO-NEVADO L, PORTAL-NUÑEZ S, ARDURA JA, CORTON M, FERNÁNDEZ-FERNÁNDEZ B, AGUILERA O, GOMEZ-GUERRERO C, MAS S, MORENO JA, RUIZORTEGA M, SANZ AB, SANCHEZ-NIÑO MD, ROJO F, VIVANCO F, ESBRIT P, AYUSO C, ALVAREZLLAMAS G, EGIDO J, GARCÍA-FONCILLAS J, ORTIZ A: 2017 update on the relationship between diabetes and colorectal cancer: epidemiology, potential molecular mechanisms and therapeutic implications. Oncotarget 8: 18456-18485, 2017. https://doi.org/10.18632/oncotarget.14472

GURAYA SY: Association of type 2 diabetes mellitus and the risk of colorectal cancer: A meta-analysis and systematic review. World J Gastroenterol 21: 6026-6031, 2015. https://doi.org/10.3748/wjg.v21.i19.6026

GURUNG M, LI Z, YOU H, RODRIGUES R, JUMP DB, MORGUN A, SHULZHENKO N: Role of gut microbiota in $\begin{array}{llllll}\text { type } 2 \text { diabetes pathophysiology. EBioMedicine } & \text { 51: } 102590,\end{array}$ https://doi.org/10.1016/j.ebiom.2019.11.051

HAO NB, LÜ MH, FAN YH, CAO YL, ZHANG ZR, YANG SM: Macrophages in tumor microenvironments and the progression of tumors. Clin Dev Immunol 2012: 948098, 2012. https://doi.org/10.1155/2012/948098

HOLLISTER EB, GAO C, VERSALOVIC J: Compositional and functional features of the gastrointestinal microbiome and their effects on human health. Gastroenterology 146: 1449-1458, 2014. https://doi.org/10.1053/j.gastro.2014.01.052

HOXHAJ G, MANNING BD: The PI3K-AKT network at the interface of oncogenic signalling and cancer metabolism. Nat Rev Cancer 20: 74-88, 2020. https://doi.org/10.1038/s41568-019-0216-7

HUA H, KONG Q, YIN J, ZHANG J, JIANG Y: Insulin-like growth factor receptor signaling in tumorigenesis and drug resistance: a challenge for cancer therapy. J Hematol Oncol 13: 64, 2020. https://doi.org/10.1186/s13045$\underline{020-00904-3}$ 
HUGON P, DUFOUR JC, COLSON P, FOURNIER PE, SALLAH K, RAOULT D: A comprehensive repertoire of prokaryotic species identified in human beings. Lancet Infect Dis 15: 1211-1219, 2015. https://doi.org/10.1016/S1473-3099(15)00293-5

HUMAN MICROBIOME PROJECT CONSORTIUM: Structure, function and diversity of the healthy human microbiome. Nature 486: 207-214, 2012. https://doi.org/10.1038/nature11234

JIANG B: Aerobic glycolysis and high level of lactate in cancer metabolism and microenvironment. Genes Dis 4: 25-27, 2017. https://doi.org/10.1016/j.gendis.2017.02.003

KASPRZAK A, ADAMEK A: Insulin-like Growth Factor 2 (IGF2) signaling in colorectal cancer-from basic research to potential clinical applications. Int J Mol Sci 20: 4915, 2019. https://doi.org/10.3390/ijms20194915

KATIRA A, TAN PH: Evolving role of adiponectin in cancer-controversies and update. Cancer Biol Med 13: 101-119, 2016. https://doi.org/10.20892/j.issn.2095-3941.2015.0092

KIM JH, BLOCK DE, MILLS DA: Simultaneous consumption of pentose and hexose sugars: an optimal microbial phenotype for efficient fermentation of lignocellulosic biomass. Appl Microbiol Biotechnol 88: 1077-1085, 2010. https://doi.org/10.1007/s00253-010-2839-1

KOSTIC AD, GEVERS D, PEDAMALLU CS, MICHAUD M, DUKE F, EARL AM, OJESINA AI, JUNG J, BASS AJ, TABERNERO J, BASELGA J, LIU C, SHIVDASANI RA, OGINO S, BIRREN BW, HUTTENHOWER C, GARRETT WS, MEYERSON M: Genomic analysis identifies association of Fusobacterium with colorectal carcinoma. Genome Res 22: 292-298, 2012. https://doi.org/10.1101/gr.126573.111

LAGIER JC, EDOUARD S, PAGNIER I, MEDIANNIKOV O, DRANCOURT M, RAOULT D: Current and past strategies for bacterial culture in clinical microbiology. Clin Microbiol Rev 28: 208-236, 2015. https://doi.org/10.1128/CMR.00110-14

MERCADO-PIMENTEL ME, ONYEAGUCHA BC, LI Q, PIMENTEL AC, JANDOVA J, NELSON MA: The S100P/RAGE signaling pathway regulates expression of microRNA-21 in colon cancer cells. FEBS Lett 589: 2388-2393, 2015. https://doi.org/10.1016/i.febslet.2015.07.010

MILOSEVIC VS, VUKMIROVIC FC, KRSTIC MS, ZINDOVIC MM, LJ STOJANOVIC D, JANCIC SA: Involvement of leptin receptors expression in proliferation and neoangiogenesis in colorectal carcinoma. J BUON 20: 100-108, 2015.

MODZELEWSKA P, CHLUDZIŃSKA S, LEWKO J, RESZEĆ J: The influence of leptin on the process of carcinogenesis. Contemp Oncol (Pozn) 23: 63-68, 2019. https://doi.org/10.5114/wo.2019.85877

MOON HS, LIU X, NAGEL JM, CHAMBERLAND JP, DIAKOPOULOS KN, BRINKOETTER MT, HATZIAPOSTOLOU M, WU Y, ROBSON SC, ILIOPOULOS D, MANTZOROS CS: Salutary effects of adiponectin on colon cancer: in vivo and in vitro studies in mice. Gut 62: 561-570, 2013. https://doi.org/10.1136/gutjnl-2012-302092

NG CW, JIANG AA, TOH EMS, NG CH, ONG ZH, PENG S, THAM HY, SUNDAR R, CHONG CS, KHOO CM: Metformin and colorectal cancer: a systematic review, meta-analysis and meta-regression. Int J Colorectal Dis 35: 1501-1512, 2020. https://doi.org/10.1007/s00384-020-03676-X

PABST O: Correlation, consequence, and functionality in microbiome-immune interplay. Immunol Rev 279: 4-7, 2017. https://doi.org/10.1111/imr.12584

PANDIT R, BEERENS S, ADAN RAH: Role of leptin in energy expenditure: the hypothalamic perspective. Am J Physiol Regul Integr Comp Physiol 312: R938-R947, 2017. https://doi.org/10.1152/ajpregu.00045.2016

PEILA R, ROHAN TE: Diabetes, glycated hemoglobin, and risk of cancer in the UK biobank study. Cancer Epidemiol Biomarkers Prev 29: 1107-1119, 2020. https://doi.org/10.1158/1055-9965.EPI-19-1623

PHILIPPA C, MIROIU R, SLEVIN M, PETCU E: An update on angiogenesis modulators with a potential therapeutic role. Vascular Cell 10, 2018. https://doi.org/10.24238/13221-10-1-179

PLAZA-DIAZ J, GOMEZ-LLORENTE C, FONTANA L, GIL A: Modulation of immunity and inflammatory gene expression in the gut, in inflammatory diseases of the gut and in the liver by probiotics. World J Gastroenterol 20: 15632-15649, 2014. https://doi.org/10.3748/wjg.v20.i42.15632

POTTER M, NEWPORT E, MORTEN KJ: The Warburg effect: 80 years on. Biochem Soc Trans 44: 1499-1505, 2016. https://doi.org/10.1042/BST20160094

QI L, CHEN J, YANG Y, HU W: Hypoxia correlates with poor survival and M2 macrophage infiltration in colorectal cancer. Front Oncol 10: 566430, 2020. https://doi.org/10.3389/fonc.2020.566430 
QIN J, LI R, RAES J, ARUMUGAM M, BURGDORF KS, MANICHANH C, NIELSEN T, PONS N, LEVENEZ F, YAMADA T, MENDE DR, LI J, XU J, LI S, LI D, CAO J, WANG B, LIANG H, ZHENG H, XIE Y, TAP J, LEPAGE P, BERTALAN M, BATTO JM, HANSEN T, LE PASLIER D, LINNEBERG A, NIELSEN HB, PELLETIER E, RENAULT P, SICHERITZ-PONTEN T, TURNER K, ZHU H, YU C, LI S, JIAN M, ZHOU Y, LI Y, ZHANG X, LI S, QIN N, YANG H, WANG J, BRUNAK S, DORÉ J, GUARNER F, KRISTIANSEN K, PEDERSEN O, PARKHILL J, WEISSENBACH J; METAHIT CONSORTIUM, BORK P, EHRLICH SD, WANG J: A human gut microbial gene catalogue established by metagenomic sequencing. Nature 464: 59-65, 2010. https://doi.org/10.1038/nature08821

RAMOS A, HEMANN MT: Drugs, bugs, and cancer: Fusobacterium nucleatum promotes chemoresistance in colorectal cancer. Cell 170: 411-413, 2017. https://doi.org/10.1016/j.cell.2017.07.018

RAMTEKE P, DEB A, SHEPAL V, BHAT MK: Hyperglycemia associated metabolic and molecular alterations in cancer risk, progression, treatment, and mortality. Cancers (Basel) 11: 1402, 2019. https://doi.org/10.3390/cancers11091402

RAO KONDAPALLY SESHASAI S, KAPTOGE S, THOMPSON A, DI ANGELANTONIO E, GAO P, SARWAR N, WHINCUP PH, MUKAMAL KJ, GILLUM RF, HOLME I, NJØLSTAD I, FLETCHER A, NILSSON P,LEWINGTON S, COLLINS R, GUDNASON V, THOMPSON SG, SATTAR N, SELVIN E, HU FB, DANESH J; EMERGING RISK FACTORS COLLABORATION: Diabetes mellitus, fasting glucose, and risk of cause-specific death. N Engl J Med 364: 829-841, 2011. https://doi.org/10.1056/NEJMoa1008862

REIMER RA, GROVER GJ, KOETZNER L, GAHLER RJ, LYON MR, WOOD S: Combining sitagliptin/metformin with a functional fiber delays diabetes progression in Zucker rats. J Endocrinol 220: 361-373, 2014. https://doi.org/10.1530/JOE-13-0484

RENEHAN AG, ZWAHLEN M, EGGER M: Adiposity and cancer risk: new mechanistic insights from epidemiology. Nat Rev Cancer 15: 484-98, 2015. https://doi.org/10.1038/nrc3967

RIONDINO S, ROSELLI M, PALMIROTTA R, DELLA-MORTE D, FERRONI P, GUADAGNI F: Obesity and colorectal cancer: role of adipokines in tumor initiation and progression. World J Gastroenterol 20: 5177-5190, 2014. https://doi.org/10.3748/wjg.v20.i18.5177

ROJAS A, AÑAZCO C, GONZÁLEZ I, ARAYA P: Extracellular matrix glycation and receptor for advanced glycation end-products activation: a missing piece in the puzzle of the association between diabetes and cancer. Carcinogenesis 39: 515-521, 2018. https://doi.org/10.1093/carcin/bgy012

SAMAD N, RAO T: Role of leptin in cancer: A systematic review. Biomed J Sci Tech Res 18: 13226-13235, 2019. https://doi.org/10.26717/BJSTR.2019.18.003091

SCALIA P, GIORDANO A, WILLIAMS SJ: The IGF-II-Insulin Receptor Isoform-A autocrine signal in cancer: actionable perspectives. Cancers (Basel) 12: 366, 2020. https://doi.org/10.3390/cancers12020366

SCHRÖTER D, HÖHN A: Role of advanced glycation end products in carcinogenesis and their therapeutic implications. Curr Pharm Des 24: 5245-5251, 2018. https://doi.org/10.2174/1381612825666190130145549

SEDIGHI M, RAZAVI S, NAVAB-MOGHADAM F, KHAMSEH ME, ALAEI-SHAHMIRI F, MEHRTASH A, AMIRMOZAFARI N: Comparison of gut microbiota in adult patients with type 2 diabetes and healthy individuals. Microb Pathog 111: 362-369, 2017. https://doi.org/10.1016/j.micpath.2017.08.038

SHEN XJ, RAWLS JF, RANDALL T, BURCAL L, MPANDE CN, JENKINS N, JOVOV B, ABDO Z, SANDLER RS, KEKU TO: Molecular characterization of mucosal adherent bacteria and associations with colorectal adenomas. Gut Microbes 1: 138-147, 2010. https://doi.org/10.4161/gmic.1.3.12360

SHI J, FAN J, SU Q, YANG Z: Cytokines and abnormal glucose and lipid metabolism. Front Endocrinol (Lausanne) 10: 703, 2019. https://doi.org/10.3389/fendo.2019.00703

SHI J, XIONG L, LI J, CAO H, JIANG W, LIU B, CHEN X, LIU C, LIU K, WANG G, CAI K: A linear dose-response relationship between fasting plasma glucose and colorectal cancer risk: systematic review and meta-analysis. Sci Rep 5: 17591, 2015. https://doi.org/10.1038/srep17591

SHIN S, EL-SABBAGH AS, LUKAS BE, TANNEBERGER SJ, JIANG Y: Adipose stem cells in obesity: challenges and opportunities. Biosci Rep 40: BSR20194076, 2020. https://doi.org/10.1042/BSR20194076

SIMPSON A, PETNGA W, MACAULAY VM, WEYER-CZERNILOFSKY U, BOGENRIEDER T: Insulin-like Growth Factor (IGF) pathway targeting in cancer: Role of the IGF axis and opportunities for future combination studies. Target Oncol 12: 571-597, 2017. https://doi.org/10.1007/s11523-017-0514-5 
ŠKRHA J JR, MURAVSKÁ A, FLEKAČ M, HOROVÁ E, NOVÁK J, NOVOTNÝ A, PRÁZNÝ M, ŠKRHA J, KVASNIČKA J, LANDOVÁ L, JÁCHYMOVÁ M, ZIMA T, KALOUSOVÁ M: Fructosamine 3-kinase and glyoxalase I polymorphisms and their association with soluble RAGE and adhesion molecules in diabetes. Physiol Res 63 (Suppl 2): S283-S291, 2014. https://doi.org/10.33549/physiolres.932790

STENMAN LK, WAGET A, GARRET C, BRIAND F, BURCELIN R, SULPICE T, LAHTINEN S: Probiotic B420 and prebiotic polydextrose improve efficacy of antidiabetic drugs in mice. Diabetol Metab Syndr 7: 75, 2015. https://doi.org/10.1186/s13098-015-0075-7

STOLARCZYK E: Adipose tissue inflammation in obesity: a metabolic or immune response? Curr Opin Pharmacol 37: 35-40, 2017. https://doi.org/10.1016/j.coph.2017.08.006

SUCHANEK S, GREGA T, NGO O, VOJTECHOVA G, MAJEK O, MINARIKOVA P, BROGYUK N, BUNGANIC B, SEIFERT B, DUSEK L, ZAVORAL M: How significant is the association between metabolic syndrome and prevalence of colorectal neoplasia? World J Gastroenterol 22: 8103-8111, 2016. https://doi.org/10.3748/wjg.v22.i36.8103

THOMAS D, APOVIAN C: Macrophage functions in lean and obese adipose tissue. Metabolism 72: 120-143, 2017. https://doi.org/10.1016/j.metabol.2017.04.005

URBANCSEK H, KAZAR T, MEZES I, NEUMANN K: Results of a double-blind, randomized study to evaluate the efficacy and safety of Antibiophilus in patients with radiation-induced diarrhoea. Eur J Gastroenterol Hepatol 13: 391-396, 2001. https://doi.org/10.1097/00042737-200104000-00015

URBANOVA M, MRAZ M, DUROVCOVA V, TRACHTA P, KLOUCKOVÁ J, KAVALKOVA P, HALUZIKOVA D, LACINOVA Z, HANSIKOVA H, WENCHICH L, KRSEK M, HALUZIK M: The effect of very-lowcalorie diet on mitochondrial dysfunction in subcutaneous adipose tissue and peripheral monocytes of obese subjects with type 2 diabetes mellitus. Physiol Res 66: 811-822, 2017. https://doi.org/10.33549/physiolres.933469

VELLA V, MILLUZZO A, SCALISI NM, VIGNERI P, SCIACCA L: Insulin Receptor Isoforms in Cancer. Int J Mol Sci 19: 3615, 2018. https://doi.org/10.3390/ijms19113615

WANG N, KHANKARI NK, CAI H, LI HL, YANG G, GAO YT, XIANG YB, SHU XO, ZHENG W: Prediagnosis body mass index and waist-hip circumference ratio in association with colorectal cancer survival. Int J Cancer 140: 292-301, 2017. https://doi.org/10.1002/ijc.30459

XU J, YE Y, WU H, DUERKSEN-HUGHES P, ZHANG H, LI P, HUANG J, YANG J, WU Y, XIA D: Association between markers of glucose metabolism and risk of colorectal cancer. BMJ Open 6: e011430, 2016. https://doi.org/10.1136/bmjopen-2016-011430

YOON KW, PARK SY, KIM JY, LEE SM, PARK CH, CHO SB, LEE WS, JOO YE, LEE JH, KIM HS, CHOI SK, REW JS: Leptin-induced adhesion and invasion in colorectal cancer cell lines. Oncol Rep 31: 2493-8, 2014. https://doi.org/10.3892/or.2014.3128

ZELENKO Z, GALLAGHER EJ: Diabetes and cancer. Endocrinol Metab Clin North Am 43: 167-85, 2014. https://doi.org/10.1016/j.ecl.2013.09.008

ZHENG J, CHEN S, ALBIERO ML, VIEIRA GHA, WANG J, FENG JQ, GRAVES DT: Diabetes activates periodontal ligament fibroblasts via NF-KB in vivo. J Dent Res 97: 580-588, 2018. https://doi.org/10.1177/0022034518755697

ZHU B, WU X, WU B, PEI D, ZHANG L, WEI L: The relationship between diabetes and colorectal cancer prognosis: A meta-analysis based on the cohort studies. PLoS One 12: e0176068, 2017. https://doi.org/10.1371/journal.pone.0176068

ZIŃCZUK J, MACIEJCZYK M, ZARĘBA K, ROMANIUK W, MARKOWSKI A, KĘDRA B, ZALEWSKA A, PRYCZYNICZ A, MATOWICKA-KARNA J, GUZIŃSKA-USTYMOWICZ K: Antioxidant barrier, redox status, and oxidative damage to biomolecules in patients with colorectal cancer. Can malondialdehyde and catalase be markers of colorectal cancer advancement? Biomolecules 9: 637, 2019. https://doi.org/10.3390/biom9100637

ZITVOGEL L, GALLUZZI L, VIAUD S, VÉTIZOU M, DAILLÈRE R, MERAD M, KROEMER G: Cancer and the gut microbiota: an unexpected link. Sci Transl Med 7: 271ps1, 2015. https://doi.org/10.1126/scitranslmed.3010473 